\title{
Front Matter: Volume 7664
}

, "Front Matter: Volume 7664," Proc. SPIE 7664, Detection and Sensing of Mines, Explosive Objects, and Obscured Targets XV, 766401 (24 May 2010); doi: $10.1117 / 12.867300$

SPIE Event: SPIE Defense, Security, and Sensing, 2010, Orlando, Florida, United SPIE. States 


\title{
PROCEEDINGS OF SPIE
}

\section{Defection and Sensing of Mines, Explosive Objects, and Obscured Targets XV}

\author{
Russell S. Harmon \\ John H. Holloway, Jr. \\ J. Thomas Broach \\ Editors
}

5-9 April 2010

Orlando, Florida, United States

Sponsored and Published by

SPIE 
The papers included in this volume were part of the technical conference cited on the cover and title page. Papers were selected and subject to review by the editors and conference program committee. Some conference presentations may not be available for publication. The papers published in these proceedings reflect the work and thoughts of the authors and are published herein as submitted. The publisher is not responsible for the validity of the information or for any outcomes resulting from reliance thereon.

Please use the following format to cite material from this book:

Author(s), "Title of Paper," in Detection and Sensing of Mines, Explosive Objects, and Obscured Targets XV, edited by Russell S. Harmon, John H. Holloway, Jr., J. Thomas Broach, Proceedings of SPIE Vol. 7664 (SPIE, Bellingham, WA, 2010) Article CID Number.

ISSN 0277-786X

ISBN 9780819481283

Published by

SPIE

P.O. Box 10, Bellingham, Washington 98227-0010 USA

Telephone +1 3606763290 (Pacific Time) · Fax +1 3606471445

SPIE.org

Copyright (@ 2010, Society of Photo-Optical Instrumentation Engineers

Copying of material in this book for internal or personal use, or for the internal or personal use of specific clients, beyond the fair use provisions granted by the U.S. Copyright Law is authorized by SPIE subject to payment of copying fees. The Transactional Reporting Service base fee for this volume is $\$ 18.00$ per article (or portion thereof), which should be paid directly to the Copyright Clearance Center (CCC), 222 Rosewood Drive, Danvers, MA 01923. Payment may also be made electronically through CCC Online at copyright.com. Other copying for republication, resale, advertising or promotion, or any form of systematic or multiple reproduction of any material in this book is prohibited except with permission in writing from the publisher. The CCC fee code is 0277-786X/10/\$18.00.

Printed in the United States of America.

Publication of record for individual papers is online in the SPIE Digital Library.

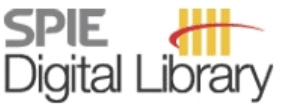

SPIEDigitalLibrary.org

Paper Numbering: Proceedings of SPIE follow an e-First publication model, with papers published first online and then in print and on CD-ROM. Papers are published as they are submitted and meet publication criteria. A unique, consistent, permanent citation identifier (CID) number is assigned to each article at the time of the first publication. Utilization of CIDs allows articles to be fully citable as soon they are published online, and connects the same identifier to all online, print, and electronic versions of the publication. SPIE uses a six-digit CID article numbering system in which:

- The first four digits correspond to the SPIE volume number.

- The last two digits indicate publication order within the volume using a Base 36 numbering system employing both numerals and letters. These two-number sets start with 00, 01, 02, 03, 04 , 05, 06, 07, 08, 09, OA, OB ... 0Z, followed by 10-1Z, 20-2Z, etc.

The CID number appears on each page of the manuscript. The complete citation is used on the first page, and an abbreviated version on subsequent pages. Numbers in the index correspond to the last two digits of the six-digit CID number. 


\section{Contents}

766402 Kalman filters applied to the detection of unexploded ordnance [7664-01] T. M. Grzegorczyk, Delpsi, LLC (United States); B. Barrowes, U.S. Army Engineer Research and Development Ctr. (United States); F. Shubitidze, Dartmouth College (United States) and Sky Research, Inc. (United States); J. P. Fernández, I. Shamatava, Dartmouth College (United States); K. A. O'Neill, U.S. Army Engineer Research and Development Ctr. (United States)

766403 Combining electromagnetic induction and automated classification in a UXO discrimination blind test [7664-02]

J. P. Fernández, Dartmouth College (United States); B. Barrowes, Dartmouth College (United States) and U.S. Army Engineer Research and Development Ctr. (United States); A. Bijamov, Dartmouth College (United States); T. Grzegorczyk, Delpsi, LLC (United States); K. A. O'Neill, Dartmouth College (United States) and U.S. Army Engineer Research and Development Ctr. (United States); I. Shamatava, Dartmouth College (United States) and Sky Research, Inc. (United States); F. Shubitidze, Dartmouth College (United States), U.S. Army Engineer Research and Development Ctr. (United States), and Sky Research, Inc. (United States)

766404 SLO blind data set inversion and classification using physically complete models [7664-03] I. Shamatava, F. Shubitidze, Sky Research, Inc. (United States) and Dartmouth College (United States); J. P. Fernández, Dartmouth College (United States); B. E. Barrowes, K. O'Neill, Dartmouth College (United States) and U.S. Army Engineer Research and Development Ctr. (United States); T. M. Grzegorczyk, Delpsi, LLC (United States); A. Bijamov, Dartmouth College (United States)

766405 Transient electromagnetic responses during the transmitter on-time [7664-04] G. M. Schultz, J. S. Miller, Sky Research, Inc. (United States); L.-P. Song, The Univ. of British Columbia (Canada); L. Pasion, Sky Research, Inc. (United States) and The Univ. of British Columbia (Canada)

766406 Target localization techniques for vehicle-based electromagnetic induction array applications [7664-05]

J. S. Miller, G. M. Schultz, F. Shubitidze, Sky Research, Inc. (United States); J. A. Marble, U.S. Army Night Vision and Electronic Sensors Directorate (United States)

766407 Applying a volume dipole distribution model to next-generation sensor data for multi-object data inversion and discrimination [7664-06]

F. Shubitidze, Dartmouth College (United States) and Sky Research Inc. (United States);

D. Karkashadze, Tbilisi State Univ. (Georgia); J. P. Fernández, Dartmouth College (United States); B. E. Barrowes, K. O'Neill, Dartmouth College (United States) and Tbilisi State Univ. (Georgia); T. M. Grzegorczyk, Delpsi, LLC (United States); I. Shamatava, Dartmouth College (United States) and Sky Research, Inc. (United States) 
766408 Comparison of the physically complete model with a simple dipole model for UXO detection and discrimination [7664-07]

F. Shubitidze, Dartmouth College (United States) and Sky Research, Inc. (United States);

J. P. Fernández, Dartmouth College (United States); B. E. Barrowes, K. O'Neill, U.S. Army Engineer Research and Development Ctr. (United States); I. Shamatava, Dartmouth College (United States) and Sky Research, Inc. (United States); A. Bijamov, Dartmouth College (United States)

766409 Source separation using sparse-solution linear solvers [7664-08] J. T. Miller, D. Keiswetter, J. Kingdon, T. Furuya, B. Barrow, T. Bell, SAIC (United States)

7664 OA Adapting physically complete models to vehicle-based EMI array sensor data: data inversion and discrimination studies [7664-09] F. Shubitidze, Dartmouth College (United States) and Sky Research, Inc. (United States); J. S. Miller, G. M. Schultz, Sky Research, Inc. (United States); J. A. Marble, U.S. Army Night Vision and Electronic Sensors Directorate (United States)

7664 OB Dual-EMI system for object classification [7664-10]

J. Marble, I. McMichael, U.S. Army Night Vision and Electronic Sensors Directorate (United States)

\section{SESSION 2 ELECTROMAGNETIC INDUCTION II}

7664 OC Upward continuation of EMI data for sensing of subsurface UXO in cluttered, multi-object cases [7664-11]

K. O'Neill, B. E. Barrowes, U.S. Army Engineer Research and Development Ctr. (United States) and Dartmouth College (United States); F. Shubitidze, J. P. Fernandez, Dartmouth College (United States); T. M. Grzegorczyk, Delpsi, LLC (United States); I. Shamatava, Dartmouth College (United States)

7664 OD Sparse model representations of target signatures for improved landmine detection using frequency-domain electromagnetic induction sensors [7664-12]

S. L. Tantum, P. A. Torrione, L. M. Collins, Duke Univ. (United States)

$7664 \mathrm{OE}$ Measured dipole expansion of discrete relaxations to represent the electromagnetic induction response of buried metal targets [7664-13]

W. R. Scott, Jr., G. D. Larson, Georgia Institute of Technology (United States)

$7664 \mathrm{OF}$ Application of $\ell_{p}$-regularized least squares for $0 \leq p \leq 1$ in estimating discrete spectrum of relaxations for electromagnetic induction responses [7664-14]

M.-H. Wei, W. R. Scott, Jr., J. H. McClellan, G. D. Larson, Georgia Institute of Technology (United States)

\section{SESSION 3 OPTICAL AND DISTURBED EARTH I}

$7664 \mathrm{OH}$ Comparison of a model of the disturbed soil spectrum to field observations [7664-17]

P. G. Lucey, Univ. of Hawai'i (United States); E. M. Winter, Technical Research Associates, Inc. (United States); K. Horton, Univ. of Hawai'i (United States) 
7664 Ol MOMS: a multi-optical sensor system for detection of surface laid mines [7664-18]

D. Letalick, I. Renhorn, O. Steinvall, N. Wadströmer, Swedish Defence Research Agency (Sweden)

$76640 \mathrm{~J}$ Quantifying the benefit of airborne and ground sensor fusion for target detection [7664-93] A. Zare, Univ. of Florida (United States); M. Silvious, U.S. Army Night Vision and Electronic Sensors Directorate (United States); R. Close, P. Gader, Univ. of Florida (United States)

$7664 \mathrm{OL} \quad$ MidIR and LWIR polarimetric sensor comparison study [7664-21]

K. Gurton, M. Felton, U.S. Army Research Lab. (United States); R. Mack, D. LeMaster, Air Force Research Lab. (United States); C. Farlow, Digital Fusion Inc. (United States); M. Kudenov, College of Optical Sciences, The Univ. of Arizona (United States); L. Pezzaniti, Polaris Sensor Technologies, Inc. (United States)

7664 OM Disturbed soil characterization workshop: post-meeting summary [7664-22]

J. M. Cathcart, Georgia Institute of Technology (United States)

\section{SESSION 5 SENSING AND DETECTING IN THE MARINE ENVIRONMENT}

7664 OQ Neyman Pearson detection of K-distributed random variables [7664-26]

J. D. Tucker, Naval Surface Warfare Ctr. Panama City Div. (United States) and Colorado

State Univ. (United States); M. R. Azimi-Sadjadi, Colorado State Univ. (United States)

7664 OR Image-based ATR utilizing adaptive clutter filter detection, LLRT classification, and Volterra fusion with application to side-looking sonar [7664-27]

T. Aridgides, M. Fernández, Lockheed Martin (United States)

7664 OS Multichannel imager for littoral zone characterization [7664-28]

Y. Podobna, J. Schoonmaker, J. Dirbas, J. Sofianos, C. Boucher, G. Gilbert, Advanced Coherent Technologies, LLC (United States)

7664 OU Inspecting the inside of the objects lying on the seafloor [7664-29]

V. Valkovic, R. Kollar, A.C.T.d.o.o. (Croatia); D. Sudac, K. Nad, J. Obhodas, Institut Ruder Boškovic (Croatia)

7664 OV Performance metrics for state-of-the-art airborne magnetic and electromagnetic systems for mapping and detection of unexploded ordnance [7664-30]

W. E. Doll, D. T. Bell, T. J. Gamey, L. P. Beard, J. R. Sheehan, J. Norton, Battelle (United States)

7664 OW Assessing EMI noise due to the marine environment to enhance underwater UXO detection and discrimination [7664-31]

A. Bijamov, Dartmouth College (United States); F. Shubitidze, Dartmouth College (United States) and Sky Research, Inc. (United States); J. P. Fernandez, Dartmouth College (United States); I. Shamatava, Sky Research, Inc. (United States) and Dartmouth College (United States); B. E. Barrowes, K. O'Neill, Dartmouth College (United States) and U.S. Army Engineer Research and Development Ctr. (United States) 
7664 OX Adaptive large-scale clutter removal from imagery with application to high-resolution sonar imagery [7664-32]

G. J. Dobeck, Naval Surface Warfare Ctr. Panama City Div. (United States)

7664 OY A method to simulate synthetic aperture sonar images with parameterized autocorrelation functions [7664-33]

J. T. Cobb, Naval Surface Warfare Ctr. Panama City Div. (United States); K. C. Slatton,

J. Principe, Univ. of Florida (United States)

$7664 \mathrm{OZ}$ Enhanced ATR using Fisher fusion techniques with application to side-looking sonar [7664-34]

C. M. Ciany, W. C. Zurawski, Raytheon Co. (United States)

\section{SESSION 6 AUTONOMOUS MINE DETECTION SYSTEM I}

766412 Autonomous mine detection system (AMDS) neutralization payload module [7664-94] M. Majerus, DE Technologies Inc. (United States); R. Vanaman, N. Wright, U.S. Army Research, Development and Engineering Command (United States)

$766413 \quad$ NIITEK-NVESD AMDS program and interim field-ready system [7664-37] M. W. Hibbard, A. Etebari, NIITEK, Inc. (United States)

766414 Autonomous mine detection system (AMDS) incorporating SFCW GPR and CWMD sensors for discrimination [7664-38]

D. O. Carlson, H. A. Duvoisin III, K. L. Johnson, M. Trishaun, L-3 CyTerra (United States)

766415 Trace detection of explosives using an in-line high-volume sampler, preconcentrator, and Fido explosives detector [7664-39]

R. Ingram, J. Sikes, ICx Nomadics, Inc. (United States)

766416 Microcantilever sensor platform for UGV-based detection [7664-40]

T. T. Lawrence, A. E. Halleck, P. S. Schuler, K. K. Mahmud, Triton Systems, Inc. (United States); D. R. Hicks, U.S. Army Night Vision and Electronic Sensors Directorate (United States)

766418 Remote robotic countermine systems [7664-42]

P. Wells, QinetiQ North America (United States)

766419 Mine detection performance comparison between manual sweeping and tele-operated robotic system [7664-43]

H. Herman, Carnegie Mellon Univ. (United States); T. Higgins, O. Falmier, Lincoln Univ. (United States); J.-S. Valois, J. McMahill, Carnegie Mellon Univ. (United States)

7664 1A Semi autonomous mine detection system [7664-44]

D. Few, R. Versteeg, Idaho National Lab. (United States); H. Herman, Carnegie Mellon Univ. (United States)

\section{SESSION 7 AUTONOMOUS MINE DETECTION SYSTEM II}

7664 1B CMMAD usability case study in support of countermine and hazard sensing [7664-45]

V. G. Walker, D. I. Gertman, Idaho National Lab. (United States) 
7664 1C Experimental design for assessing the effectiveness of autonomous countermine systems [7664-46]

I. Chappell, M. May, F. L. Moses, Institute for Defense Analyses (United States)

7664 1D Modular countermine payload for small robots [7664-47]

H. Herman, Carnegie Mellon Univ. (United States); D. Few, R. Versteeg, Idaho National Lab. (United States); J.-S. Valois, J. McMahill, M. Licitra, E. Henciak, Carnegie Mellon Univ. (United States)

$7664 \mathrm{lE} \quad$ Soldier experiments and assessments using SPEAR speech control system for UGVs [7664-48] J. Brown, C. Blanco, Think-A-Move, Ltd. (United States); J. Czerniak, iRobot Corp. (United States); B. Hoffman, Think-A-Move, Ltd. (United States); O. Hoffman, iRobot Corp. (United States); A. Juneja, L. Ngia, T. Pruthi, D. Liu, Think-A-Move, Ltd. (United States)

7664 IF Behavior based control of robotic payloads for detection, neutralization, and interrogation of explosive hazards [7664-49]

D. J. Bruemmer, C. W. Nielsen, R. S. Hartley, J. Green, 5D Robotics, Inc. (United States)

\section{SESSION 8 EXPLOSIVES DETECTION}

7664 1G Utilizing upconverting phosphors for the detection of TNT [7664-50]

G. Glaspell, U.S. Army Engineer Research and Development Ctr. (United States); J. S. Tabb, Agave BioSystems (United States); A. Shearer, Authentix (United States); J. Wilkins, C. Smith, R. Massaro, U.S. Army Engineer Research and Development Ctr. (United States)

$76641 \mathrm{H} \quad$ Xsense: using nanotechnology to combine detection methods for high sensitivity handheld explosives detectors [7664-51]

M. S. Schmidt, N. Kostesha, F. Bosco, J. K. Olsen, Technical Univ. of Denmark (Denmark);

C. Johnsen, K. A. Nielsen, J. O. Jeppesen, Univ. of Southern Denmark (Denmark); T. S. Alstrøm, J. Larsen, M. H. Jakobsen, Technical Univ. of Denmark (Denmark); T. Thundat, Oak Ridge National Lab. (United States); A. Boisen, Technical Univ. of Denmark (Denmark)

$766411 \quad$ Feasibility of bulk explosives detection using photoneutron spectroscopy [7664-52] J. E. McFee, A. A. Faust, K. A. Pastor, Defence Research and Development Canada (Canada)

$76641 \mathrm{~J} \quad$ Advances in standoff detection of trace explosives by infrared photo-thermal imaging [7664-53]

C. A. Kendziora, R. Furstenberg, M. Papantonakis, V. Nguyen, U.S. Naval Research Lab. (United States); J. Stepnowski, Nova Research, Inc. (United States); R. A. McGill, U.S. Naval Research Lab. (United States)

7664 1K Explosives standoff detection using Raman spectroscopy: from bulk towards trace detection [7664-54] A. Pettersson, S. Wallin, H. Östmark, A. Ehlerding, I. Johansson, M. Nordberg, H. Ellis, A. Al-Khalili, Swedish Defence Research Agency (Sweden) 
$7664 \mathrm{IL} \quad$ Fusing chlorophyll fluorescence and plant canopy reflectance to detect TNT contamination in soils [7664-56]

J. C. Naumann, U.S. Army Engineer Research and Development Ctr. (United States); K. Rubis, D. R. Young, Virginia Commonwealth Univ. (United States)

7664 iN Liquid explosives detection in transparent containers [7664-58]

M. Gaft, Laser Distance Spectrometry (Israel); L. Nagli, Laser Distance Spectrometry (Israel) and Tel Aviv Univ. (Israel)

766410 High-resolution soil moisture mapping using operational optical satellite imagery [7664-91] J. M. H. Hendrickx, B. J. Harrison, B. Borchers, G. Rodríguez-Marín, New Mexico Institute of Mining and Technology (United States); S. Howington, J. Ballard, U.S. Army Corps of Engineers (United States)

\section{SESSION 9 MULTISENSOR DETECTION}

7664 IP Evaluation test of ALIS in Cambodia for humanitarian demining [7664-59]

M. Sato, Tohoku Univ. (Japan)

7664 1Q Development of dual sensor hand-held detector [7664-60]

M. Sezgin, TÜBITAK UEKAE (Turkey)

$7664 \mathrm{lR}$ Fusion techniques for hybrid ground-penetrating radar: electromagnetic induction landmine detection systems [7664-61]

M. Laffin, M. A. Mohamed, A. Etebari, M. Hibbard, NIITEK, Inc. (United States)

7664 is Fusion of ground-penetrating radar and electromagnetic induction sensors for landmine detection and discrimination [7664-62]

M. P. Kolba, P. A. Torrione, L. M. Collins, Duke Univ. (United States)

7664 IT Feature extraction and object recognition in multi-modal forward looking imagery [7664-63] G. Greenwood, S. Blakely, Portland State Univ. (United States); D. Schartman, B. Calhoun, J. M. Keller, Univ. of Missouri-Columbia (United States); T. Ton, D. Wong, U.S. Army Night Vision and Electronic Sensors Directorate (United States); M. Soumekh, Univ. at Buffalo (United States)

$76641 \mathrm{U}$ Improved detection and false alarm rejection using FLGPR and color imagery in a forward-looking system [7664-64]

T. C. Havens, C. J. Spain, K. C. Ho, J. M. Keller, Univ. of Missouri-Columbia (United States);

T. T. Ton, D. C. Wong, U.S. Army Night Vision and Electronic Sensors Directorate (United

States); M. Soumekh, Univ. at Buffalo (United States)

7664 IW Dual sensor platforms for UXO/landmine detection using GPR and EMI [7664-66]

J. Marble, U.S. Army Night Vision and Electronic Sensors Directorate (United States); K. Hong,

Defence Science and Technology Organisation (Australia)

\section{SESSION 10 SENSING POTPOURRI I}

7664 1X Carrier tracking and tunable passband filters for TDM-LDV mine detection [7664-67]

R. Burgett, J. M. Sabatier, V. Aranchuk, The Univ. of Mississippi (United States) 
7664 IY Outdoor synthetic aperture acoustic ground target measurements [7664-68]

S. Bishop, U.S. Army Night Vision and Electronic Sensors Directorate (United States);

T.-A. Ngaya, J. Vignola, J. Judge, The Catholic Univ. of America (United States); J. Marble,

P. Gugino, U.S. Army Night Vision and Electronic Sensors Directorate (United States);

M. Soumekh, Soumekh Consultant (United States); E. Rosen, Institute of Defense Analyses

(United States)

766412 Comparison of indoor robot localization techniques in the absence of GPS [7664-69]

R. Vincent, B. Limketkai, M. Eriksen, SRI International (United States)

\section{SESSION 11 SENSING POTPOURRI II}

766420 Development of an integrated soils laboratory for modeling and detection applications [7664-70]

W. R. Folks, Bevilacqua Research Corp. (United States); R. E. North, L. D. Wakeley,

S. S. Jackson, J. R. Kelley, R. M. Castellane, J. R. McKenna, U.S. Army Corps of Engineers (United States)

$766421 \quad$ Common IED exploitation target set ontology [7664-71]

D. J. Russomanno, J. Qualls, The Univ. of Memphis (United States); Z. Wowczuk, P. Franken,

W. Robinson, ARES Systems Group, LLC (United States)

766423 Development of x-ray and gamma-ray CZT detectors for homeland security applications [7664-73]

K. Lee, J. W. Martin, A. B. Garson III, M. Beilicke, Q. Guo, Q. Li , Washington Univ. in St. Lovis (United States); G. De Geronimo, Brookhaven National Lab. (United States); M. Groza,

A. Burger, Fisk Univ. (United States); H. Krawczynski, Washington Univ. in St. Louis (United States)

\section{SESSION 12 SIGNAL PROCESSING I}

766424 Automatic forest canopy removal algorithm for underneath obscure target detection by airborne lidar point cloud data [7664-74]

L.-D. Chang, K. C. Slatton, V. Anand, P.-W. Liu, H. Lee, Univ. of Florida (United States);

M. V. Campbell, U.S. Army Engineer Research and Development Ctr. (United States)

766425 Forward looking anomaly detection via fusion of infrared and color imagery [7664-75]

K. Stone, J. M. Keller, M. Popescu, T. C. Havens, K. C. Ho, Univ. of Missouri-Columbia (United States)

766426 Exploiting spatial distributions for minefield detection in cluttered environment [7664-76]

A. Trang, S. Agarwal, T. Broach, T. Smith, U.S. Army Night Vision and Electronic Sensors

Directorate (United States)

766427 GPU-based processing for airborne detection [7664-77]

D. Singiresu, S. Agarwal, S. Vulli, H. Ramakrishnan, Missouri Univ. of Science and Technology (United States) 
766428 Multiple instance feature learning for landmine detection in ground-penetrating radar data [7664-78]

J. Bolton, P. Gader, Univ. of Florida (United States); H. Frigui, Univ. of Louisville (United States)

766429 Information-based sensor management for the intelligent tasking of ground-penetrating radar and electromagnetic induction sensors in landmine detection pre-screening [7664-79]

M. P. Kolba, L. M. Collins, Duke Univ. (United States)

\section{SESSION 13 SIGNAL PROCESSING II}

7664 2A Effect of radar undesirable characteristics on the performance of spectral feature landmine detection technique [7664-80]

K. C. Ho, Univ. of Missouri-Columbia (United States); P. D. Gader, J. N. Wilson, Univ. of Florida (United States); H. Frigui, Univ. of Louisville (United States)

7664 2B Anomaly defection in forward looking infrared imaging using one-class classifiers [7664-81] M. Popescu, K. Stone, T. Havens, D. Ho, J. Keller, Univ. of Missouri-Columbia (United States)

7664 2C Depth estimation of buried objects using wavelet transform and statistical hypothesis testing [7664-82]

A. B. Yoldemir, M. Sezgin, TÜBITAK UEKAE (Turkey)

7664 2D Detection of bulk explosives using the GPR only portion of the HSTAMIDS system [7664-83]

J. Tabony, D. O. Carlson, H. A. Duvoisin III, J. Torres-Rosario, L-3 CyTerra (United States)

$76642 \mathrm{E} \quad$ Locally adaptive detection algorithm for forward-looking ground-penetrating radar [7664-84]

T. C. Havens, K. C. Ho, J. Farrell, J. M. Keller, M. Popescu, Univ. of Missouri-Columbia (United States); T. T. Ton, D. C. Wong, U.S. Army Night Vision and Electronic Sensors Directorate (United States); M. Soumekh, Univ. at Buffalo (United States)

$76642 \mathrm{~F} \quad$ Preprocessing of GPR data for syntactic landmine detection and classification [7664-85] A. O. Nasif, K. J. Hintz, N. Peixoto, George Mason Univ. (United States)

$76642 \mathrm{G}$ Upper bound on false alarm rate for landmine detection and classification using syntactic pattern recognition [7664-86]

A. O. Nasif, B. L. Mark, K. J. Hintz, N. Peixoto, George Mason Univ. (United States)

$76642 \mathrm{H} \quad$ Nonparametric Bayesian time-series modeling and clustering of time-domain ground penetrating radar landmine responses [7664-87]

K. D. Morton, Jr., P. A. Torrione, L. Collins, Duke Univ. (United States)

766421 Context-dependent feature selection using unsupervised contexts applied to GPR-based landmine detection [7664-88]

C. R. Ratto, P. A. Torrione, L. M. Collins, Duke Univ. (United States) 
$76642 \mathrm{~J} \quad$ Landmine detection using ensemble discrete hidden Markov models with context dependent training methods [7664-89]

A. Hamdi, O. Missaoui, H. Frigui, Univ. of Louisville (United States); P. Gader, Univ. of Florida (United States)

7664 2K Comparison of different classification algorithms for landmine detection using GPR [7664-90] A. Karem, A. Fadeev, H. Frigui, P. Gader, Univ. of Louisville (United States)

Author Index 
Downloaded From: https://www.spiedigitallibrary.org/conference-proceedings-of-spie on 25 Apr 2023

Terms of Use: https://www.spiedigitallibrary.org/terms-of-use 


\title{
Conference Committee
}

\author{
Symposium Chair \\ Michael T. Eismann, Air Force Research Laboratory (United States) \\ Symposium Cochair \\ William Jeffrey, HRL Laboratories, LLC (United States) \\ Conference Chairs
}

Russell S. Harmon, U.S. Army Research Office (United States)

John H. Holloway, Jr., Naval Surface Warfare Center Panama City Division (United States)

J. Thomas Broach, U.S. Army Night Vision and Electronic Sensors Directorate (United States)

Program Committee

Leslie M. Collins, Duke University (United States)

Gerald J. Dobeck, Naval Surface Warfare Center (United States)

Paul D. Gader, University of Florida (United States)

John E. McFee, Defence Research and Development Canada (Canada)

James M. Sabatier, The University of Mississippi (United States)

Motoyuki Sato IV, Tohoku University (Japan)

Miranda A. Schatten, U.S. Army Night Vision and Electronic Sensors Directorate (United States)

Waymond R. Scott, Jr., Georgia Institute of Technology (United States)

Miranda Silvious, U.S. Army Night Vision and Electronic Sensors Directorate (United States)

Richard C. Weaver, U.S. Army Night Vision and Electronic Sensors

Directorate (United States)

\section{Session Chairs}

1 Electromagnetic Induction I

Fridon Shubitidze, Dartmouth College (United States)

Benjamin E. Barrowes, U.S. Army Engineer Research and Development Center (United States)

2 Electromagnetic Induction II

Waymond R. Scott, Jr., Georgia Institute of Technology (United States) 
Stacy L. Tantum, Duke University (United States)

Optical and Disturbed Earth I

J. Michael Cathcart, Georgia Tech Research Institute (United States)

Miranda Silvious, U.S. Army Night Vision and Electronic Sensors

Directorate (United States)

$4 \quad$ Optical and Disturbed Earth II

J. Michael Cathcart, Georgia Tech Research Institute (United States)

Miranda Silvious, U.S. Army Night Vision and Electronic Sensors

Directorate (United States)

$5 \quad$ Sensing and Detecting in the Marine Environment

Gerald J. Dobeck, Naval Surface Warfare Center Panama City Division (United States)

James T. Cobb, Naval Surface Warfare Center Panama City Division (United States)

6 Autonomous Mine Detection System I

Eloisa Lara, U.S. Army Night Vision and Electronic Sensors Directorate (United States)

Michael May, Institute for Defense Analyses (United States)

7 Autonomous Mine Detection System II

Eloisa Lara, U.S. Army Night Vision and Electronic Sensors Directorate (United States)

Michael May, Institute for Defense Analyses (United States)

8 Explosives Detection

Andrzej W. Miziolek, U.S. Army Research Laboratory (United States)

Henric Östmark, Swedish Defence Research Agency (Sweden)

9 Multisensor Detection

Motoyuki Sato IV, Tohoku University (Japan)

Jay A. Marble, U.S. Army Night Vision and Electronic Sensors

Directorate (United States)

10 Sensing Potpourri I

Steven S. Bishop, U.S. Army Night Vision and Electronic Sensors

Directorate (United States)

William R. Folks, U.S. Army Corps of Engineers (United States)

11 Sensing Potpourri II

Steven S. Bishop, U.S. Army Night Vision and Electronic Sensors Directorate (United States)

William R. Folks, U.S. Army Corps of Engineers (United States) 
12 Signal Processing I

James M. Keller, University of Missouri-Columbia (United States)

Sanjeev Agarwal, Missouri University of Science and Technology (United States)

13 Signal Processing II

James M. Keller, University of Missouri-Columbia (United States)

Sanjeev Agarwal, Missouri University of Science and Technology (United States)

14 Signal Processing III

Paul D. Gader, University of Florida (United States)

Peter A. Torrione, Duke University (United States) 
Downloaded From: https://www.spiedigitallibrary.org/conference-proceedings-of-spie on 25 Apr 2023

Terms of Use: https://www.spiedigitallibrary.org/terms-of-use 